\title{
DIAPORTHE CAULIVORA: AGENTE CAUSAL DE CANCRO DEL TALLO PREDOMINANTE EN CULTIVOS DE SOJA DEL SUDESTE BONAERENSE
}

\author{
SÁNCHEZ, M.C. ${ }^{1} ;$ RIDAO, A. del C. ${ }^{1}$ \& COLAVITA, M.L. ${ }^{1}$
}

\begin{abstract}
RESUMEN
El cancro del tallo (CTS) ha sido la enfermedad más destructiva de la soja en el sudeste de la provincia de Buenos Aires en los últimos ciclos agrícolas. Considerando la inserción actual del cultivo en los sistemas productivos de esta zona, que el CTS es una enfermedad prevalente y que Diaporthe caulivora (Dc) es el agente causal predominante en Argentina, es importante conocer la identidad del agente prevalente en el área. Los objetivos fueron reconocer por características morfológicas las especies del complejo Diaporthe/Phomopsis presentes en cultivos de soja, en los ciclos agrícolas 2010/11-2011/12-2012/13, y confirmar molecularmente mediante PCR-RFLP, que la especie predominante causante de síntomas de CTS fue Dc. De 39 aislamientos, 61\% correspondió a Dc, 26\% a P. longicolla, sólo uno a $D$. p. var. sojae y cuatro no pudieron ser determinados. No se detectó $D$. p. meridionalis. El agente causal predominante en la zona de estudio fue $D c$.

Palabras clave: Glycine max (L.) Merr.; Diaporthe/Phomopsis; D. phaseolorum var. caulivora.
\end{abstract}

\begin{abstract}
Diaporthe caulivora: predominant causal agent of stem canker in soybean crops in the southeast of Buenos Aires province.

Stem canker (SC) has been the most destructive disease of soybean in the southeast of Buenos Aires in the last agricultural cycles. Considering the current inclusion of the soybean in the production systems in this area, that the SC is a prevalent disease, and that Diaporthe caulivora (Dc) is the predominant causal agent in Argentina, it is important to know the identity of the agent prevalent in the area. The objectives of the study were to recognize by morphology the species of the Diaporthe/Phomopsis complex present in soybean crops during the agricultural cycles 2010/11-2011/122012/13, and confirmed using PCR-RFLP that the predominant species causing symptoms of SC was $D c$. Out of 39 isolates, $61 \%$ corresponded to $D c, 26 \%$ to P. longicolla, only isolation to $D$. $p$. var. sojae, and four could not be determined. D. p. meridionalis were not detected. The predominant causal agent in the zone of the study was $D c$.

Key words: Glycine max (L.) Merr.; Diaporthe/Phomopsis; D. phaseolorum var. caulivora.
\end{abstract}

1.- Facultad de Ciencias Agrarias, UNMdP. C.C. 276 (7620) Balcarce, provincia de Buenos Aires. Email: maclarasanchez@gmail.com

Manuscrito recibido el 27 de julio de 2015 y aceptado para su publicación el 2 de febrero de 2016. 